\title{
De grote partij in het vermogensrecht
}

\author{
Redactioneel
}

\author{
Mr.J.J. Valken mr. R. Meijer*
}

In 2020 besloten 305 buitenlandse bedrijven naar Nederland te verhuizen, goed voor 8600 banen en $€ 1,9$ miljard aan investeringen in de eerste drie jaar. ${ }^{1}$ Een van de belangrijkste aanjagers voor de komst van nieuwe bedrijven blijft de Brexit. In februari 2021 berichtte het Ministerie van Economische Zaken en Klimaat dat sinds het referendum in 2016218 Brexitbedrijven ons land hebben gekozen. Bovendien was het ministerie in gesprek met nog 550 Brexitbedrijven die een overstap of uitbreiding naar Nederland overwegen. ${ }^{2}$

Een van de factoren die het Nederlandse vestigingsklimaat bepalen, is de juridische infrastructuur. Het gaat daarbij in de eerste plaats om de bescherming van private eigendomsrechten en het functioneren van de rechtspraak. De Nederlandse juridische infrastructuur functioneert gemiddeld genomen erg goed. Van Velthoven schatte in 2005 dat dit goede functioneren in vergelijking met het wereldgemiddelde een bijdrage levert aan de Nederlandse economische groei van zo'n $0,8 \%$ per jaar. ${ }^{3}$

Dat betekent niet dat Nederland op zijn lauweren kan rusten. In 2019 concludeerde de visitatiecommissie gerechten dat het functioneren van de rechtspraak onder druk staat door onderbezetting en ICT-problemen. ${ }^{4}$ Empirisch onderzoek laat zien dat grote handelszaken te kampen hebben met lange doorlooptijden. ${ }^{5}$ Wij weten uit ervaring dat de coronacrisis daar geen verbetering in heeft gebracht.

Er zijn ook de nodige ontwikkelingen in het recht zelf. Nieuwe wetten zoals de Wet afwikkeling massaschade in

* Mr. J.J. Valk is advocaat bij De Brauw Blackstone Westbroek te Amsterdam en redacteur van dit tijdschrift. Mr. R. Meijer is advocaat bij Hausfeld te Amsterdam en redacteur van dit tijdschrift.

1. Invest in Holland \& Netherlands Foreign Investment Agency, Results 2020 (raadpleegbaar via rijksoverheid.nl/documenten/jaarverslagen/ 2021/02/18/invest-in-holland--nfia-results-2020).

2. Ministerie van Economische Zaken en Klimaat, Corona, Brexit en vestigingsklimaat sturen komst buitenlandse bedrijven, 18 februari 2021 (rijksoverheid.nl/actueel/nieuws/2021/02/18/corona-brexit-envestigingsklimaat-sturen-komst-buitenlandse-bedrijven).

3. B.C.J. van Velthoven, De waarde van de juridische infrastructuur voor de Nederlandse economie, Den Haag: Raad voor de rechtspraak 2005, p. 18.

4. Rapport visitatie gerechten 2018. Goede rechtspraak, sterke rechtsstaat, Den Haag: Raad voor de rechtspraak 2019.

5. R.R. Verkerk, F. van Dijk \& D. Pistora, De berechting binnen een redelijke termijn, TCR 2020, p. 153-170. collectieve actie (WAMCA) ${ }^{6}$ en de Wet homologatie onderhands akkoord (WHOA $)^{7}$ zullen door grote bedrijven worden meegenomen bij hun besluit om naar Nederland te verhuizen. Hetzelfde geldt voor de nimmer aflatende stroom aan Europese richtlijnen en verordeningen. Zelfs individuele rechterlijke uitspraken, zoals het recente vonnis in de klimaatzaak tegen Shell, ${ }^{8}$ zullen in overweging worden genomen.

Dit themanummer beziet het Nederlandse vermogensrecht een keer niet vanuit het perspectief van de consument, maar vanuit het perspectief van de grote partij. Wat kunnen Brexitbedrijven in Nederland verwachten? In hoeverre komt het Nederlandse recht aan hun behoeften tegemoet? Zijn er obstakels en hoe kunnen die worden weggenomen?

Dit nummer trapt af met een van de beruchtste onderwerpen voor ondernemers: consumentenbescherming. De Graaf laat in zijn bijdrage zien dat een ondernemer die zakendoet met consumenten, te maken krijgt met een overvloed aan wetgeving uit Europa en Nederland die allesbehalve consistent en coherent is. Hij richt zich tot de wetgever met vier geboden waarmee naar zijn idee meer consistent en coherent vorm kan worden gegeven aan de informatieplichten van ondernemers ten opzichte van consumenten: volg het normale spraakgebruik, wees consistent in woordkeus, moderniseer de manieren waarop informatie ter beschikking mag worden gesteld, voorkom herhaling en werk gelaagd.

Veel van deze geboden gelden ook voor het opstellen van contracten. Beenders en Valk illustreren in hun bijdrage aan de hand van de chronologie van het contract - precontractuele fase, uitleg, exoneraties bij niet-nakoming en beëindiging - dat het Nederlandse recht partijen die commercieel contracteren wel eens voor verrassingen stelt. Dat geldt zeker voor AngloAmerikaanse partijen en hun juristen. Beenders en Valk laten echter ook zien dat partijen die verrassingen, en de risico's die daarmee gepaard gaan, veelal kunnen voorkomen of mitigeren door te investeren in een goed contract.

6. Wet van 20 maart 2019 tot wijziging van het Burgerlijk Wetboek en het Wetboek van Burgerlijke Rechtsvordering teneinde de afwikkeling van massaschade in een collectieve actie mogelijk te maken (Stb. 2019, 130).

7. Wet van 7 oktober 2020 tot wijziging van de Faillissementswet in verband met de invoering van de mogelijkheid tot homologatie van een onderhands akkoord (Stb. 2020, 414).

8. Rb. Den Haag 26 mei 2021, ECLI:NL:RBDHA:2021:5337. 
Twee aandachtspunten bij contracten tussen ondernemers zijn de wettelijke betaaltermijnen en de daaraan gekoppelde wettelijke handelsrente. Grooten bespreekt in zijn artikel het recente wetsvoorstel waarin de maximaal toegestane betaaltermijn van grote ondernemingen aan MKB'ers wordt verkort tot dertig dagen. Hij betoogt dat het wetsvoorstel, net als vorige pogingen om betalingsachterstanden terug te dringen, in de praktijk niet zal werken door de afhankelijkheid van de MKB'ers van hun grote klanten. Hij stelt daarom handhaving door de Autoriteit Consument en Markt voor.

Handhaving door een toezichthouder, maar dan de Autoriteit Persoonsgegevens, is ook de stok achter de deur in het privacyrecht. Het aantal handhavingsacties neemt de afgelopen tijd toe en privacy staat steeds meer op de radar van de media, het publiek en bedrijven. Laan en Bakker laten in hun bijdrage zien dat het privacyrecht verweven is met allerlei hoeken van het vermogensrecht. Aan de orde komen overeenkomsten, in het bijzonder gegevensverwerkingsovereenkomsten, persoonsgegevens in faillissementen, en privacy bij fusies en overnames. $\mathrm{Zij}$ concluderen dat, mede gezien de toenemende handhavingsacties, bij deze verwevenheid in de praktijk wellicht wat beter stil kan worden gestaan.

Hiervoor noemden wij al even de WAMCA, die het sinds 1 januari 2020 mogelijk maakt om in Nederland in een collectieve actie schadevergoeding te vorderen. Een blik op het centraal register voor collectieve vorderingen ${ }^{9}$ leert dat deze mogelijkheid vooral wordt gebruikt tegen de Nederlandse Staat en tegen grote bedrijven. Horeman en De Monchy bespreken in hun artikel de summiere ondeugdelijkheidstoets in de WAMCA. In de ontvankelijkheidsfase van de WAMCA-procedure toetst de rechter onder andere of de collectieve vordering niet summierlijk ondeugdelijk is. Horeman en De Monchy betogen dat deze toets zwaarder moet worden ingevuld dan tot nu toe in de beperkte rechtspraak wordt gedaan. $\mathrm{Zij}$ stellen dat dat niet alleen in het belang van de gedaagde is, maar ook in het belang van de gedupeerden en van de claimorganisatie.

Tot slot gaan ook Santman en Philips in op de WAMCA, maar dan vanuit het perspectief van de procesfinancier. Daarbij gaan zij in op verschillende vragen die spelen in verband met de WAMCA, waaronder de manier waarop de financieringslasten door de procederende belangenorganisatie in geval van winst ten laste kunnen worden gebracht van alle belanghebbenden die profiteren van de collectieve schadeafwikkeling ('common fund'-doctrine), en in hoeverre de succesvergoeding of kosten van financiering ten laste kunnen worden gebracht van de aangesproken partij.

9. Raadpleegbaar via rechtspraak.nl/Registers/centraal-register-voorcollectieve-vorderingen. 